\title{
Effect of wheat seed dressing fungicides, botanicals and bio-control agent on Karnal bunt incidence in natural condition
}

\author{
Shrvan Kumar $^{1 *}$, Dhanbir Singh ${ }^{2}$, Subhash Dhancholia ${ }^{2}$ and Asha Sinha ${ }^{1}$ \\ ${ }^{1}$ Mycology and Plant Pathology, IAS, Banaras Hindu University, Varanasi-221005 (U.P.), INDIA \\ ${ }^{2}$ Department of Plant Pathology CSK HPKV, Palampur -176062 (H.P.), INDIA \\ *Corresponding author. E-mail:shrvankb@gmail.com \\ Received: August 27, 2016; Revised received: May 1, 2017; Accepted: October 7, 2017
}

\begin{abstract}
In this study the efficacy of four fungicides, three botanicals and one bio-control agent under field conditions revealed that all the treatments gave reduction of Karnal bunt over check at significant level $(P=0.05)$. Maximum disease control was achieved with Tilt 25EC (48.72\%) followed by Bavistin 50WP (47.08 \%), Vitavax 75WP (45.30\%) and Raxil 2DS (37.61\%). Among botanicals $L$. camara was adjudged best as it gave 41.88 per cent disease control. However, seed treatment of $T$. viride (Ecoderma) resulted in 28.21 percent disease control. In all treatments over all disease control level was ranged between 28.21 to 48.72 per cent. For effective disease management, source of primary inoculum must be destroy. Primary inoculum of Karnal bunt is present in seed. Therefore, eco-friendly seed treatment of wheat is necessary process for diseases management.
\end{abstract}

Keywords: Karnal bunt, Neovossia indica, Triticum aestivum, T. viride (Ecoderma)

\section{INTRODUCTION}

Wheat (Triticum aestivum L.) is the most popular grain of the world and geographical is found between 30 $55^{\circ} \mathrm{N}$ latitude in the Northern hemisphere and between $20-40^{\circ} \mathrm{S}$ in Southern hemisphere (Kumar, 2014). The Karnal bunt of wheat disease (Neovossia indica (Mitra) Mundkur) was first reported by Mitra in 1931 on wheat (Triticum aestivum L.) from Karnal (Haryana) in India. Around 70 countries quarantine constraint on wheat from countries where Karnal bunt is known to occur (Lari et al. 2006). In Himachal Pradesh zone-I is a hot spot for KB. Therefore, a domestic response does not allow seed for cultivation purpose in zone-II and zone -III. Karnal bunt causes heavy losses in wheat production mainly in Northern and Central India. The disease is spreading at an alarming rate in the states, due to its soil, seed and airborne nature. Weather conditions in this region are conductive for Karnal bunt as in Punjab. The highest KB incidence $(53.3 \%)$ was recorded from Jammu region of J\&K followed by Punjab (33.7\%). The Karnal bunt incidence in 2015-16 crop seasons was lower than the 2014-15 (IIWBR, 2016-17).

The mechanism of antagonism was attributed to antibiosis in culture filtrates. Trichoderma spp. have been reported to secrete vast anti-microbial secondary metabolites and hydrolytic enzymes i.e. cellulases, chitinases, lipasees, proteases, etc., which are help in host recognition and pathogen control (Srivastava et al. 2010; Harman, 2011 and Harman et al., 2012; Hermosa et al., 2012, Shanmugaiah et al., 2009). Besides, the production of a large variety of volatile secondary metabolites by Trichoderma like ethylene, hydrogen cyanide, alcohols, aldehydes, alamethicine and ketones up to $\mathrm{C} 4$ chain- length also play an important role in biocontrol (Landreau et al., 2002). The inhibitory effect of L. camara on teliospore germination may be attributed due to the presence of antisporulant compound like Pentacyclic triterpenoids (Barceloux and Donald 2008). Application of Tilt 25EC was found effective highly effective in Karnal bunt prone area of Punjab (Aujla and Sharma 1990, Kumar and Singh, 2014). All efforts to control the disease through cultural practices and chemical treatment have been futile. The only alternative and long term control measures to avert this disease.

\section{MATERIALS AND METHODS}

Dry seed treatment with fungitoxicants i.e. Vitavax $75 \mathrm{WP}(2.5 \mathrm{~g} / \mathrm{kg})$, Bavistin 50WP $(2.5 \mathrm{~g} / \mathrm{kg})$, Raxil 2DS $(1.0 \mathrm{~g} / \mathrm{kg})$ and antagonist- T. viride $(5.0 \mathrm{~g} / \mathrm{kg})$ were done by mixing seed and fungitoxicants/antagonists separately in polythene begs and mixed properly before sowing. In case of Tilt $(1.0 \mathrm{~mL} / 1)$ and phyto-extracts (25\%) seed was dipped for 30 minutes. Seed was dried in shade before showing. All treatments were replicated thrice in a randomized block design (RBD). Seed of susceptible wheat variety UP-2338 was used for sowing at Experiment farm of HAREC, Dhaulakuan. The plot size was kept $1.5 \mathrm{~m} \times 2.0 \mathrm{~m}$ with line spacing of 25 $\mathrm{cm}$. Data on seed germination; Karnal bunt incidence and grain yield were recorded. Data was analysed 
RBD test by the help of CPSC-1 software. Karnal bunt incidence (KBI) was recorded after threshing as per formula of Aujla et al. (1989a).

\section{RESULTS AND DISCUSSION}

A field trial was conducted to see the effect of promising seed dresser fungicides, phyto-extracts and biocontrol agents on the incidence of Karnal bunt of wheat under natural infection condition at Dhaulakuan. The data presented in Table-1 indicated that all the treatments supported good germination and significantly incidence of KB over check (11.72\%). However, maximum disease control was achieved with Tilt $25 \mathrm{EC}$ as it resulted in $48.72 \%$ disease control followed by Bavistin 50WP (47.08\%) and Vitavax 75WP (45.30\%). Bavistin 50WP and Tilt 25EC did not show any significant difference in their efficacy. However, these differed significantly from Vitavax 75WP. Lantana camara seed treatment resulted in $41.88 \%$ disease control followed by Raxil 2DS (37.61\%). Eucalyptus globulus, Ageratum conyzoids and Trichoderma viride gave $36.75,34.19$ and $28.21 \%$ disease control, respectively. None of the treatments showed phytotoxicity symptoms. Seed treatment with fungicides, phytoextracts and bio-control agent was not much effective as these resulted in 28.21 to 48.72 per cent control of KB under natural conditions. Kumar and Singh (2014) stated that an effective management practice against $\mathrm{KB}$ of wheat, integration of fungicidal seed treatment with foliar sprays of phyto-extracts, bio-control agent and fungicide revealed that seed treatment with Tilt 25EC $(0.1 \%)$ and few sprays of Tilt 25EC $(0.1 \%)$, one at flag leaf stage followed by another at 50 per cent emergence of spikes and seed treatment of Tilt plus one spray of L. camara and one spray of Tilt 25EC gave cent per cent disease control under field conditions. Seed treatment with Tilt 25EC plus one spray of $T$. viride at flag leaf stage and another spray L. camara at 50 per cent emergence of spikes gave 95.84 per cent disease control.

Srivastava (2014) conducted two years field trials re- vealed that seed treatment with Trichoderma viride recorded a disease incidence of 0.64 per cent and that of Tricoderma harzianum was 0.95 per cent. Bacterial biocontrol agents Pseudomonas flouresence (Resident) and $P$. flouresence (PDBC) recorded a disease incidence of 0.99 and 1.16 per cent. Distilled water used as control recorded a disease incidence of 1.92 per cent. Aujla and Sharma (1990) also reported that fungicides applied as seed and soil treatment were not much effective. However, combination of soil treatment with Brassicol (quintozene), seed treatment with carbendazim and thiram for primary inoculum and spray treatment with propiconazole gave $80.8 \% \mathrm{~KB}$ of wheat. Aujla et al. (1989b) reported effectiveness of Blitox, Emisan, Thiram and Bavistin on seed treatment against Karnal bunt. They suggested that fungicide seed treatment need to be coupled with carrier chemicals to eradicate internal seed borne inoculum. Carbendazim and seed protectants (Thiram, Emison, Foltaf and Blitox) when applied as a slurry resulted in 100 per cent inhibition of surface contamination of teliospores.

Sharma and Basandrai (2000) reported that wheat seed treatment with $T$. viride resulted in $20 \%$ control of Karnal bunt of wheat. T. viride in the present study also gave 28 per cent disease control. Sharma et al. (1996) studied the antagonistic potential of Gliocladium and Trichoderma spp. against $N$. indica and found that seed dip treatment of bunted seed in culture filtrate, had no effect on seed borne inoculum. However, a powdered formulation of T. viride @ $4 \mathrm{~g} / \mathrm{kg}$ seed significantly reduced teliospores germination. Antagonistic activity of Trichoderma spp., Gliocladium deliquescens and $G$. virens against $N$. indica have also been reported by other workers in vitro and in vivo condition (Amer et al., 2000; Kumar, 2013 and Sharma et al., 2014).

\section{Conclusion}

Seed treatment with fungicides, phyto-extracts and bio -control agent was not much effective as these resulted

Table 1. Effect of wheat seed treatments with fungicides, botanicals and bio-control agent on yield and incidence of Karnal bunt.

\begin{tabular}{lccccc}
\hline \multirow{2}{*}{ Treatments } & \multirow{2}{*}{$\begin{array}{c}\text { Dose } \\
\text { (\%) }\end{array}$} & Germination (\%)* & \multicolumn{2}{c}{ Karnal bunt } & \multicolumn{2}{c}{$\begin{array}{c}\text { Average yield (q/ } \\
\text { ha)* }\end{array}$} \\
& 0.1 & $86.33(69.11)^{* *}$ & $6.05(14.24)$ & $48.72(44.03)$ & 35.00 \\
Tilt 25EC & 0.25 & $93.67(73.83)$ & $6.20(14.41)$ & $47.08(43.31)$ & 34.33 \\
Bavistin 50WP & 0.25 & $86.33(69.11)$ & $6.50(14.76)$ & $45.30(41.84)$ & 34.33 \\
Vitavax 75WP & 0.1 & $83.67(67.48)$ & $7.32(15.69)$ & $37.61(37.76)$ & 31.67 \\
Raxil 80 WP & 25 & $94.67(75.93)$ & $6.63(14.92)$ & $41.88(41.18)$ & 37.33 \\
Lantana camara & 25 & $91.33(73.10)$ & $7.76(16.17)$ & $34.19(35.51)$ & 34.33 \\
A. conyzoids & 25 & $91.33(73.10)$ & $7.46(15.85)$ & $36.75(37.02)$ & 35.33 \\
Eucalyptus globulus & 0.5 & $92.67(74.32)$ & $8.43(16.87)$ & $28.21(31.98)$ & 32.67 \\
T. viride & & $87.00(69.74)$ & $11.72(20.01)$ & - & 31.00 \\
Check & & 4.28 & 0.268 & 1.29 & - \\
CD $(\mathrm{P}=0.05)$ & & & &
\end{tabular}

Note: *Average of three replications, Seed treated with fungicides, botanicals and bio-control agent was done before sowing, **Figure in parenthesis are arc sine values 
in 28.21 to 48.72 per cent control of Karnal bunt under natural conditions. This indicated that seed treatment alone was not sufficient to contain Karnal bunt under field conditions. Therefore, integration of fungicide, bio-control agent and phyto-extract is cheaper and ecofriendly practice for the of Karnal bunt of wheat. This may provide a better management of the disease.

\section{ACKNOWLEDGEMENTS}

I beseech the entire array of words of thanks given and reverence to fall in judiciously with their full expression to mark gratitude to my "Reverent teacher" and renowned Associate Director of Research Dr. Dhanbir Singh, Hill Agricultural Research and Extension Centre, Dhaulakuan, District-Sirmour (H.P.) for help in my research.

\section{REFERENCES}

Amer, G.A.M., Singh, D.V., Aggarwal, R. and Prem-Dureja. (2000). Microbial antagonism to Neovossia indica, causing Karnal bunt of wheat. International Conference on Integrated Plant Disease Management for Sustainable Agriculture. N. Delhi, India. p. 1281.

Aujla, S.S. and Sharma, I. (1990). Evaluation of fungicides against Karnal bunt disease of wheat. Journal of Research (PAU) 27 (3): 434-436.

Aujla, S.S., Kaur, S. and Sharma, I. (1989b). Chemical seed treatment for control of Karnal bunt of wheat. Plant Protection Bulletin, Faridabad 41(3-4): 20-21.

Aujla, S.S., Sharma, I., and Singh BB. (1989a). Rating scale for identifying of wheat varieties resistant to Neovossia indica. Indian Phytopathology 42(1): 161-162.

Barceloux and Donald G. (2008). Medical Toxicology Natural substsnces: Foods, Fungi, Medicinal Herbs, Plants and Venomous plants. John Willey and Sons. pp. 867868.

Harman, G.E. (2011). Multifunctional fungal plant symbionts: new tools to enhance plant growth and productivity. New Phytologist Commentry, Forum (3): 647-649.

Harman, G.E., Herrera-Estrella, A.H., Horwitz, B.A. and Lorito, M. (2012). Special issue: Trichoderma - from Basic Biology to Biotechnology. Microbiology. 158:1-2

Hermosa, R., Viterbo, A., Chet, I. and Monte, E. (2012). Plant-beneficial effects of Trichoderma and of its genes. Microbiology. 158: 17-25

IIWBR (2016-17). Wheat Crop Health Newsletter, 22(1):1- 8.website: www.dwr.res.in

Kumar S. (2013). Trichoderma: A biological weapon for managing plant diseases and Promoting sustainability. Int. J. Agrl. Sc. and Vet. Med. 1(3):106-121

Kumar S. and Singh D. (2014). Integrated management of Karnal bunt of wheat. Jr. of Indus. Pollution Control, 30(2): 305-308.

Kumar, S., Singh, D., and Pandey V. K.(2014). Field screening of wheat genotypes against Karnal bunt caused by Neovossia indica (Mitra) Mund. Elect. J. of Pl. Breeding, 5(3): 602-604.

Landreau A, Pouchus Y.F., Sallenave-Namont C., Biard J.F., Boumard M.C., Robiou du P.T., Mondeguer F., Goulard C. and Verbist J.F. (2002). Combined use of LC/MS and a biological test for rapid identification of marine mycotoxins produced by Trichoderma koningii. Journal of Microbiology Method 48: 181-194.

Lari, M. Carris, Lisa, A., Castlebury and Goates, Blair J. (2006). Non-systemic Bunt Fungi-Tilletia indica and $T$. horrida: A review of History, Systematics and Biology. Annual Review of Phytopathology 44: 113-133.

Mitra, M. (1931). A new bunt on wheat in India. Annals of Applied Biology 18(2): 178-179.

Shanmugaiah, V., Balasubramanian, N., Gomathinayagam, S., Manoharan, P.T. and Rajendran, A. (2009). Effect of single application of Trichoderma viride and Pseudomonas fluorescens on growth promotion in cotton plants. Afri. J. Agri. Res. 4(11): 1220-1225.

Sharma, B.K. and Basandrai, A.K. (2000). Effectiveness of some fungicides and bio-control agents for the management of Karnal bunt of wheat. Indian Journal of Mycology and Plant pathology 30(1): 76-78.

Sharma, I., Nanda G.S., Sharma, S. and Kaloty, P. K. (1996). Preliminary studies on the use of bio-agents in the management of Karnal bunt of wheat. Plant Disease Research 11(1): 12-18.

Sharma, P., Sharma M., Raja, M. and Shanmugam V. (2014). Status of Trichoderma research in India: A review. Indian Phytopathology 67 (1): 1-19

Srivastava J.N. (2014). Effectiveness of Cultural and Biological Management Approaches For Karnal Bunt Disease of Wheat Caused By Neovossia indica (Mitra) Mundkur. Inter. J. of Scie. Res., 3(6):1-5.

Srivastava R., Khalid, A., Singh, U.S. and Sharma, A.K. (2010). Evaluation of arbuscular mycorrhizal fungus, fluorescent Pseudomonas and Trichoderma harzianum formulation against Fusarium oxysporum f. sp. lycopersici for the management of tomato wilt. Biological Control. 53: 24-31. 